\begin{tabular}{|c|c|}
\hline $\begin{array}{l}\text { ULREV Unram Law Review } \\
\text { ISSN: 2548-9267 |E-ISSN: 2549-2365 }\end{array}$ & $\begin{array}{l}\text { Volume 1, Issue 1, April } 2017 \\
\text { Open Access at: http://unramlawreview.unram.ac.id/index.php/ulr/user }\end{array}$ \\
\hline
\end{tabular}

UNRAM Law Review is licensed under a Creative Commons Attribution 4.0 International License, which permits unrestricted use, distribution, and reproduction in any medium, provided the original work is properly cited. ISSN: 2548-9267 | e-ISSN: 2549-2365._Open Access at: http://unramlawreview.unram.ac.id/index.php/ulr/user

\begin{tabular}{c|c|c|c|c|}
$\begin{array}{c}\text { Volume } \\
1\end{array}$ & Issue & Page & April & ISSN: 2548-9267 \\
\hline
\end{tabular}

\title{
Confidentiality Guarantee of Tax Information Against The Property of Taxpayer in Management Examination and The State Financial ResponsibilitiesWhich Conducted by The Audit Board
}

\author{
Johannes JohnyKoynja \\ Faculty of Law Mataram University \\ St. Majapahit No. 62 Mataram 83125, Telp. (0370), 633035, Fax. 626954 \\ Email: johny@gmail.com
}

\begin{abstract}
This research analysis meant to find out legal consideration used byConstitution judge, whether in accordance or not to legal principles, moral andsocial justice. Therefore, this article tend to place problems that linked to conflict of norm in term of The Audit Board (BPK) authorities over a good and compliance Taxpayerl,and progressive related The Constitutional Court decision of The Audit Board(BPK) authorities of a good and compliance taxpayer in the context of The 1945Constitution of The Republic of Indonesia at its proportion in order tostraightening the consistency of rule of law in Indonesia's legal system, for theshake of completion of logical degree of optimal norm.Intrinsically, decision in the case of petition for Judicial Review of the Act Number 28 of 2007 on the Third Amendment to the Act Number 6 of 1983 on the General Taxation Provisions and Procedures against the 1945 Constitution of the Republic of Indonesia, can be made guidance (stelling) to the happening ofopaqueness norm or obscurity norm (vague van normen) which flange at thehappening conflict of norm (geschiljd van normen) related existence of twoimportance of law between The Audit Board (BPK) and Taxpayers which both ofthe same owning of rights which under the aegis of Constitution.
\end{abstract}

Keywords: $\quad$ Management, Examination, Financial, Audit Board, Taxpayers

\section{INTRODUCTION}

This study departs from the issue conceived from a conflict between two interests that are equally protected by the constitution that led to the occurrence of overlapping authority and conflicts of interest.Namely: First, the interest in the form of constitutional rights of the Taxpayer on his property as referred to Article 28G, Paragraph (1) of the 1945 
Constitution ${ }^{1}$.In this case, the guarantee of secrecy reserved for any information that has been given to the state (tax authorities) in respect of its obligations to pay taxes according to the principle of self-assessment; Secondly, the benefit in the form of the constitutional authority of the Audit Board (BPK)under Article 23Eparagraph (1) of the 1945 Constitutionto conduct an audit of state finances freely and independently ${ }^{2}$ thus requiring them to check all the documents related to the audit of the management and financial responsibility of the state ${ }^{3}$.

Meanwhile, the elucidation of Article 34, paragraph (2a) of the Act Number 28 of 2007 on the General Provisions and Tax Procedures said to inhibit the authority of the Audit Board (BPK)in exercising his constitutional because not all the data and/or information can be provided to the Audit Board as "state institutions", but only information about the identity of the Taxpayer and general information on taxation. Thus, the provisions of Article 34, paragraph (2a) letter b andElucidation of Article 34,paragraph (2a) of the Act Number 28 of 2007 on the General Provisions and Tax Procedures, by the Audit Board considered real and expressly deny and contrary to Article 23E paragraph (1) of the 1945 Constitutionso it is very detrimental to the constitutional authority of the Audit Board, because the existence of such provisionstheAudit Board may not be able to examine the state revenue derived from the tax sector freely and independently, while a tax is a contributing taxpayer to the state, which is one form of revenue or at least part of the country's financial acceptance under Article 2 of the Act Number 17 of 2003 on the State finances.

For that the Audit Boardfiled a judicial review against the Act Number 28 of 2007 on the Third Amendment to the Act Number 6 of 1983 on the General Taxation Provisions and Procedures, in particular Article 34 paragraph (2a) letter b and the Elucidation of Article 34 Paragraph (2a), Problems arise when the Constitutional Court through its decision Number 3/PUU-VI/2008 on the Authority of the Audit Boardto audit the management and financial responsibility of the state to tax information on the property taxpayer, stating that the Audit Boardpetitioncan not be accepted.

1 The Article 28G, Paragraph (1) of the 1945 Constitution says that"Every person has the right to protection of personal self, family, honor, dignity, and property under his control, and has the right to feel secure and protected from the threat of fear to do or not to do something is a human right".

${ }^{2}$ The Article 23E, paragraph (1) of the 1945 Constitution stated, "To check the management and accountability of state finances held an Audit Board that is free and independent". (bolding of Researchers).

${ }^{3}$ The Article 9, paragraph (1) of the Act Number 15 of 2006 on theAudit Board stated"In performing its duties, the Audit Boardis authorized to request information and/or documents that must be provided by each person, an organizational unit of the Central Government, Local Government, State institutions other, Bank Indonesia, the General Services Agency, Regional owned enterprises, and institutions or other bodies managing state finances". 
Constitutional Court Decision Number 3/PUU-VI/2008is one of the many

Constitutional Court decision that by some quarters is considered quite controversial, that is still being debated, so for a while that decision may be regarded as a benchmark or as a preassumption of the above problems, because at first glance the decision assessed not accommodate the principle of transparency in an effort to implement the general principles of good governance.

Based on the problems mentioned above, there are two questions of urgency in the research related to the conflict norm constitutional authority of Audit Board to information on property tax taxpayer, namely:

1. Where is the conflict of norms related to the constitutional authority of the Audit Board (BPK)to information on property tax taxpayer?

2. How does the actual implementation of the Taxpayer confidentiality to information on property tax Taxpayers with the implementation of self assessment system in the Indonesian taxation system?

\section{DISCUSSION}

\section{Constitutional Authority of the Audit Board (BPK)to Information of Property Taxes on Taxpayers}

In Legal studies, we always faced with solving legal problems and how to solve the conflict. Similarly, against the decision of the Constitutional Court Number 3/PUUVI/2008on the Authority of the Audit Board (BPK) to audit the management and financial responsibility of the state to tax information on the property taxpayer. For that, $\mathrm{Noll}^{4}$ confirms thatthe Legal studies it is judicial science (rechtspraakwetenschap). It means that the legal studies when viewed from the glass eyes of the judge, containing at least three (3) characteristics, namely: First, with regard to individual events; Second, the application of a norm or rule (rule of law); and Third, the completion of a conflict.

In this case, the Constitutional Court is not only a "funnel law". If it must be the sound of the legislation, it must be interpreted as the Judge freedom in legal discovering (rechtsvinding) were considered fair ${ }^{5}$. So in order legal finding by the judge, in this case the

${ }^{4}$ WG. Van der Velden, (1988) De Ontwikkeling van de Wetgevingswetenschap. Lelystad: Koninklijke Vermande, P.21-22

${ }^{5}$ In this case if there is a void norm, then the Judge can undertake the legal construction, the trial Judge can employ several methods to legal discovery (rechtsvinding) namely with argumentum a contrario, argumentum per analogiam and legal rarefaction. 
Judge of Constitutional Court was the subject of a major legal finding ${ }^{6}$.

The existence of the Audit Boardas a state institution performing the examination and supervision of state finances are directed to perform corrective-strategic examination of the use of state money, as well as basically the Audit Boardreflects the division of state power in the 1945 Constitution 7 . Determination oftheAudit Boardas a state institution should ideally be based on philosophical objectivity, that the authority of the Audit Boardthat the exercise should be equal and free from the influence of other state institutions, especially related to the one of the objects of the tests. However, the philosophical concept of objectivity that is supposed to run the Audit Board, it tends to be interpreted as "free and independent", as stated in Article 23E paragraph (1) the 1945 Constitution. In fact, for a financial audit institutions as well as the Audit Board, objectivity performance is considered more important precisely when compared with the meaning of "free and independent" in institutions, but in the exercise performance actually leads to subjective permanent assessment ${ }^{8}$.

Explicitly, the competencies of the Audit Boardis the power legitimized by law so that the implementation of a state organ function defined by initiation and formulation of the laws and regulations. The authority is to be understood also as an authority which is a legitimate authority, in this case the authority was created because it used to shape the role, so that it appears right that is used to organize certain actions ${ }^{9}$.

The Judge of Constitutional Courtin its decision confirms that in

the Act Number 28 of 2007 on the Third Amendment to the Act Number 6 of 1983 on the General Taxation Provisions and Procedures set is the balance of rights and obligations between the state and taxpayers. This relates to the application of the principle of Self

\footnotetext{
${ }^{6}$ According to Paul Scholten, legal inventionbyJudges is something other than just the application of regulations on events, sometimes even very often the case that the rules must be found, either by way of interpretation or by way of analogy or legal concretion

(Rechtsvervijning). Meanwhile, according to SudiknoMertokusumo, legal invention (rechtsvinding) is the law-making process by the Judge or other legal officers were given the task of applying the law to the events of a legal concrete. In other words, the process of concretization or individualization of legal regulation (das sollen) that are common with the remembrance of concrete events (das sein ) specific. What is important in the legal inventionis how to find or legal discoveringto concrete events. See: SudiknoMertokusumo, (1993) Chapters about Legal Invention, Jakarta: Citra Aditya Bakti, P.4-12

${ }^{7}$ Jimly Asshiddiqie. (2006). Development and Consolidation Post-Reformation State Institutions, Jakarta: Constitutional Press, P.192

${ }^{8}$ Alberto Alesina, Nouriel Roubini, and Gerald D.Cohen. (1997). Political Cycles and the Macroeconomy Massachusetts: Massachusetts Institute of Technology, P.22

${ }^{9}$ Guy Benveniste. (1997). Bereaucracy, translated by Sahat Simamora, Birokrasi, Jakarta: Rajawali Press, P.42-43
} 
Assessment ${ }^{10}$ used in the tax collection system in Indonesia. The application of the principle of Self-Assessmenthas consequences, namely that countries in casu the Government through the Minister of Finance (and officials in the environment) as the tax authorities banned ${ }^{11}$ to notify the other party all she knew or to him by Taxpayers ${ }^{12}$, while on the other hand there is an obligation to provide information to officials of state institutions or government agencies that have the authority to carry out checks in the financial sector where the state tax sector (in this case the right of the state to collect taxes) is included. (bolding of Researchers).

In the case of the above mentioned examination conducted by the Audit Board, the results will then be submitted to the House of Representatives (DPR), Regional Representative Council (DPD) and Regional People's Representative Assembly (DPRD) in accordance with the authority and after it declared open to the public ${ }^{13}$. Although there is a provision stating that the examination report declared open to the public shall not include a report containing state secret $^{14}$, but still raises the question of whether the personal data Taxpayers may be regarded as a state secret? If it is considered a state secret, it continues to be unclear within the limits of whichtheAudit Board may enter personal data Taxpayer. Conversely, if the Taxpayer personal data is not considered state secrets, then it means he is subject to the requirement to be declared as data is open to the public, which means that conflicting to Article 34 paragraph (1) of the Act Number 28 of 2007 on the Third Amendment to the Act Number 6 of 1983 on the General Taxation Provisions and Procedures. (bolding of Researchers).

In such a situation then there has been a collision/conflict norm (geschiljd van normen) or conflict of legal norms (antinomy) between two legal interests are equally protected by the constitution. In its decision, the Judge of Constitutional Court considers that there is

\footnotetext{
${ }^{10}$ Since 1983, the tax collection system in Indonesia adheres to the Self Assessment System replaces the original tax collection system is Official Assessment System. This matter stipulated in the Act Number 6 of 1983 which has undergone two changes, the first change of the Act Number 10 of 1994 and changes in both the Act Number 16 of 2000 on General Provisions and Procedures for Taxation. Self Assessment System adopted Indonesian tax laws provide the full confidence of Taxpayers to calculate, pay, and report tax obligations to the tax authorities, or in other words that Taxpayers were given full confidence to exercise the rights and obligation in accordance with the legislation in force.

${ }^{11}$ In principle, the disclosure of information without the owner's consent is a form of tort. Then the Directorate General of Taxation officials will open a document owned by Taxpayer will essentially exposed a criminal offense as stipulated also in the same legislation.

12 Article 34 paragraph (1) of the Act Number 28 of 2007 on the Third Amendment to the Act Number 6 of 1983 on the General Taxation Provisions and Procedures.

${ }^{13}$ Article 7 paragraph (1) in conjunction with paragraph (5) the Act Number 15 of 2006 on the Audit Boardin conjunction with Article 19 paragraph (1) of the Act Number 15 of 2004 on the Management and State Financial Responsibility.

14 Article 19 paragraph (2) of the Act Number 15 of 2004 on the Management and Financial Responsibility State
} 
disharmony between legislations, in casu the Act Number 28 of 2007 on the Third Amendment to the Act Number 6 of 1983 on theGeneral Provisions and Tax Proceduresand regulations related to finance state ${ }^{15}$, which was the cause of the clash between two legal interests are equally protected by the constitution, which on the one hand their legal interest in the form of constitutional rights of the Taxpayer on his property as referred to Article 28G paragraph(1) the 1945 Constitution ${ }^{16}$, in this case guarantee of confidentiality which are reserved for any information that has been given to the state (tax authorities) in respect of its obligations to pay taxes according to the principle of self-assessment.

But on the other side, there is a legal interest in the form of constitutional authority of the Audit Board (BPK) to audit state finances freely and independently ${ }^{17}$ so that requiring them to check all the documents related to the audit of the management examination and responsibility state financial ${ }^{18}$.

The Judge of Constitutional Courtin its consideration, in the case of judicial review of the Act Number 28 of 2007 on the Third Amendment to the Act Number 6 of 1983 on theGeneral Provisions and Tax Procedures, which is really not a matter of dispute over the constitutional authority of state institutions, which can not be determined loss on the constitutional authority of the Audit Boardas a result of the enactment of Article 34 paragraph (2a) letter $b^{19}$ and Elucidation of Article 34 paragraph (2a) ${ }^{20}$ the Act Number 28 of 2007 on the Third Amendment to the Act Number 6 of 1983 on theGeneral Provisions and Tax Procedures. Although the Audit Boardqualify as a party may file a petition for a law against the 1945 Constitution, but therefore can not be determined any loss constitutional authority of the Audit Board, then the requisite legal standing conditions as referred to in Article 51A

\footnotetext{
${ }^{15}$ The Act Number 17 of 2003 on State Finance, The Act Number 1 of 2004 on State Treasury, The Act Number 15 of 2004 on the management examination and Responsibility State Financial, TheAct Number 15 of 2006 on the Audit Board.

${ }^{16}$ Article 28G (1) the 1945 Constitutionstated that "Everyone has the right to protection of self, family, honor, dignity, and property under his control, and has the right to feel safe and protected from the threat of fear to do or not to do something that is right basic".

17 Article 23E paragraph (1) the 1945 Constitution stated "To examine the management and accountability of state finances held the Audit Board of free and independent".

${ }^{18}$ Elucidation of Article 9 paragraph (1) letter b of the Act Number 15 of 2006 on the Audit Board

19 The Norms contained in the provisions of Article 34 paragraph (2a) letter bthe Act Number 28 of 2007 on the Third Amendment to the Act Number 6 of 1983 on the General Provisions and Tax Procedures, determines that "Officials tax and/or experts only able to give information to the Audit Board after got the determination by the Finance Minister".(bolding of Researchers).

${ }^{20}$ Elucidation of Article 34 Paragraph (2a) the Act Number 28 of 2007 on the Third Amendment to the Act Number 6 of 1983 on the General Provisions and Tax Procedures are also considered to limiting the constitutional function of the Audit Board, because not all of the data and/or information can be given to the Audit Board as "state institutions", but only information about the identity of the Taxpayer and general information about taxation.
} 
paragraph (2) letter b of the Act Number 8 of 2011 on the Amendment to the Act Number 24 of 2003 on theConstitutional Court, not fulfilled so that the petition should be declared unacceptable (nietontvankelijkverklaard).

Writer considered that the practice of law in Indonesia showed that the situation is strongly influenced by legal positivism, positivism legislation (legisme), so that the legal profession also tend to think of positivistic or legistik in decisions. In the positivist view, the law is only what is explicitly stated in the valid legal rule (legislation).

According to Writer, the positive law on the one hand has the advantage of the guarantee of legal certainty (rechtzekerheid). However on the other hand, positive law has an ambiguous and paradoxical duality. These facts tend to give the impression that the existence of legal positivism is a law that does not have the constancy of the establishment. So the dualism of positive law is at once confusing substantive law although written (law is written in the book), but not necessarily a law practice (law in practice) in accordance with the substance of the law itself, but veered off from the teachings of the law, so sometimes the judge's decision (judges made law) is very contradiction and controversy with a sense of justice (social justice unjustifiable). Fitting the phrase that states "the law actually made to be broken, if there is no violation, then the law does not become effective as a fact in the sense that the logical-rationalist, is the law".

Legal arguments of the Judge of Constitutional Courtin its decision, according to the author is not enough just by virtue of legal norms written and then directly applied to the legal facts, for the formulation of norms tend to be abstract caused opaqueness normor obscurity norm(vague van normen) which leads to conflict norm (geschiljd van normen), so to the Constitutional Court can use one of several legal principles, including: the principle of lexspecialis, the principle of lex superior derogatlegi priori and lex posterior derogatlegiinferiori. Given the legal principles greatly help judge (rechter) to sharpen interpretationand helped in the imposition of analogy and directed to provide corrections to the legislations.

Furthermore, the clash between two legal interests are equally protected by the constitution, is due solely because the strengthening of the application of neo-conservatism ${ }^{21}$

\footnotetext{
${ }^{21}$ Neo-conservatism is defined as a stream of philosophical schools of adapting the concept of the Law of Nature of Thomas Hobbes who want the law as a form of discipline and willingness desired some groups, particularly those owned by the state. Flow neokonsevatisme regard the State as institutions ruling against its citizens. Neo-conservatism looked at as a system of tax collection is holistic so as to raise awareness that is both concrete and subtanstif for the adherents of these states is a tax collection system and not stages. Neo-
} 
that it has been formalized in the 1945 Constitution related to the understanding of state financial inspection, namely:

1. State as the highest power factor in the financial field in any country;

2. The requirement for the intervention of the state organs throughout all stages of investigation mechanism of state finances; and

3. The strengthening of the influence of the state bureaucracy in the examination in the taxation sector.

Finance the expanded definition of the object of a state that tends to have increased the role of the Audit Boardas a state audit institution which would lead to the interesting $\operatorname{paradox}^{22}$

In this case according to the researchers, the Audit Boardactually has not authorityto determine and take over the state financial audit in the tax sector, especially in the stages of management, given the management of an administrative nature so it has the discretion to determine the procedures for their management. Besides, can not be equated in the examination accountability contained in the State Budget(APBN).

Moreover imperfektivitas or imperfection of the State Finance Law after amendment of the 1945 Constitution seen in the legislation governing state finances. To that end, the legislations governing the state finances ${ }^{23}$ should contain a cornerstone philosophy behind which a substance thought lawmakers on State Finances, including must be formulated in fundamental science (het dekken der kennis), as well as formulations also must be organized on the premise economical (ekonomischedenkgesetz), the formulation of the provision should avoid the substance that is repeated and/or conflicting between chapter one to chapter other (wiedersprüchlos), including the scope formulation of the substance of the legislation governing state finances must be comprehensive (dekken het van de rechtsstof), then the latter

conservatism that all processes in the tax collection should be checked by the agency inspectors. This means that the rationality of neo-conservatism also see taxation as an integrative state finance. Neo-conservatism examine the audit institutions of public as the institution should audit the levies that are, will be, and has collected country, and has been categorized as state finances, including taxes and other charges coercive. See: MDA Freeman, Introduction to Jurisprudence (London: Sweet \& Maxwell Ltd., 2001), P. 146-147

${ }^{22}$ Mark Moore in Robert D.Behn. (2001). Rethingking Democratic Accountability, Washington, DC: Brookings Institution Press, P.35

${ }^{23}$ The Act Number 17 of 2003 on the State Finance, The Act Number 1 of 2004 on the State Treasury, The Act Number 15 of 2004 on the Management Examination and Responsibility State Financial, The Act Number 15 of 2006 on the Audit Board. 
should be useful for their intended purpose (doelmatig $)^{24}$.

Writer added that the Academic Manuscript Draft Amendment the Act Number 17 of 2003 on the State Finance ${ }^{25}$, also emphasized their efforts to change the paradigm related to the authority of theAudit Board is expected to emphasize his investigations on the evaluation of policies of government funds (macro-strategic) not on examination of technical (micro technical) to see the same function which is run by the General Accounting Office (GAO) in the United States and the National Accounting Office in the United Kingdom, the examination was conducted on the financial audit, compliance audit, and internal control system. Examination done is post-audit by implementing a program evaluations, no longer voucher audits $^{26}$.

\section{B Implementation of taxpayer Confidentiality Guarantee Related to Tax Information against Property of Taxpayers with its Implementation of Self Assessment System}

Taxpayers have the right to have all the data related to himself and his business kept secret by tax officials. In some countries these rules are clearly stipulated. Taxpayer data can only be granted if it is necessary to process the data necessary investigation as stipulated in legislation.

In the discussion of the OECD ${ }^{27}$ entitled 'Taxpayers' Rights and Obligations - Practice Note"by the OECD Committee of Fiscal Affairs on Tax Administration explained that in democracies, Taxpayers will have some basic rights and obligations in relation to the government and the ministries / agencies under the government. In a survey of member countries of OECD, held in 1990, summed up some of the basic rights granted to taxpayers, among others: (1) The right to be informed, assisted and heard; (2) The right of appeal; (3) The right to pay no more than the correct amount of tax; (4) The right to certainty; (5) The right to privacy; dan (6) the right to confidentiality and secrecy. (Bolding of Researchers)

In the paragraphs that discuss the right to confidentiality, stated that “...the information

\footnotetext{
${ }^{24}$ Arifin P. Soeria Atmadja, Law State Finance After 60 years of Indonesian Independence: Problems and Prospects for Indonesia, Articles, Indonesian Judicial Monitoring Society, Faculty of Law, University of Indonesia, P.7

${ }^{25}$ The participation of Researchers in activities Committee IV of Regional Representatives Council (DPD) Related of Test Validity against Revised the The Act Number 17 of 2003 on the State Finance, located in Building Rector University of Mataram, Tuesday, February 14, 2012, Pkl.09.30-13:00 pm

${ }^{26}$ Harry S.Heaven. (2011). The Evolution of the General Accounting: Voucher From Audits to Program Evaluations, 1990 in Academic Paper Draft Amendment the Act Number 17 of 2003 on the State Finance, the Expert Team Revised State Finance Act, the Regional Representative Council (DPD), Jakarta, in June 2011, P.68

${ }^{27}$ OECD, (2003). Taxpayers' Rights and Obligations - Practice Note. Tax guidance series: Centre for Tax Policy and Administration
} 
available to the tax authorities on the affairs of a taxpayer is confidential and will only be used for the purposes specified in tax legislation. Tax legislation usually imposes very heavy penalties on tax officials who misuse confidential information and the confidentiality rules that apply to tax authorities are far stricter than those applying to other government departments". From these statements may be taken several key points, among others: First, the information received by the tax authorization is confidential, and only used specifically for the tax legislation; Second, the absence of sanctions for those who misuse the tax information; and Third, the rules of giving confidential information to third parties more difficult than in the department of government (executive). Exemplified also The Taxpayers Charter, astatementabout the behavior (the term refers to the rights and obligations if in Indonesia) is expected of officials and Taxpayers.

In order to better provide fairness in taxation is the balance of rights between the state and the rights of citizens Taxpayers. The Act on General Provisions and Tax Procedures has accommodated the various rights of taxpayers. One Taxpayer rights are poured into it is confidential Taxpayer data. Taxpayers have the right to protection of confidentiality on all information that has been conveyed to the Directorate General of Taxes in order to carry out the provisions of taxation. Besides, the other parties who perform tasks in the field of taxation are also prohibited from disclosing confidential Taxpayer, including experts, like-linguists, accountants, lawyers appointed by the Director General of Taxes to help the implementation of the Act Taxes.

The obligation to keep taxation data or data obtained from the Taxpayer has existed since the Act of Taxes before the reform of 1983, which in Article 44 of the Company Tax Ordinance (PPs) in 1925, under Articles 21 and 22 of the Income Tax Ordinance (PPd) in 1944 and Article 33 of the Sales Tax Ordinance (PPN) in 1951. As it grows, only then there are special rules governing the confidentiality of the taxpayer data that must be kept by the tax authorities as stipulated in the Act Number 28 of 2007 on the Third Amendment to the Act Number 6 of 1983 on theGeneral Provisions and Tax Procedures (KUP) of the first published namely the Act Number 6 of 1983 and continues to experience improvements to the the Act Number 16 of 2009 on the Determination of Government Regulation in Lieu of Act Number 5 of 2008 on the Fourth Amendment Act Number 6 of 1983 on The General Provisions and Tax Procedures become Act. Taxpayer confidentiality regarding the data that must be kept by the tax authorities in Indonesia is regulated intheAct ontheGeneral Provisions and Tax Procedures (UU KUP).TheArticle 34 paragraph (1) and (2) of the Act ontheGeneral Provisions and Tax 
Procedures, reads:

(1) Each officer is prohibited notify the other party of everything known or disclosed to him by the taxpayer in order to position or the task to carry out the provisions of tax legislation. (Bolding of Researchers)

(2) The prohibition referred to in paragraph (1) shall also apply to experts appointed by the Director General of the Tax to assist in the implementation of the provisions of tax legislations.

Furthermore, in Article 34 (2a), (3), (4) and (5) of the Act ontheGeneral Provisions and Tax Procedures (UU KUP) arranged that the specific provisions that are excluded from the provisions referred to in Article 34 paragraph (1) and (2) are as follows :

(2a) Excepted from the provisions referred to in paragraph (1) and (2) are:

a. Officials and experts who act as a witness or an expert witness in court, or

b. Officers and/or experts appointed by the Finance Minister to give information to officials of state institutions or government agencies shall conduct checks in the field of public finance.

(3) For the sake of the country, the Minister of Finance is authorized to give permission in writing to an officer referred to in paragraph (1) and the experts referred to in paragraph (2) in order to provide information and show written evidence from or about taxpayer to the person appointed. (Bolding of Researchers)

(4) For the purpose of examination in court in a criminal case or civil, at the request of the judge in accordance with the Criminal Procedure Code and the Civil Procedure Code, the Minister of Finance can give written permission to the officials referred to in paragraph (1), and experts referred to in paragraph (2), to provide and demonstrate the written evidence and information available to him Taxpayer. (Bolding from Researchers)

(5) Request the judge referred to in paragraph (4) shall mention the suspect's name or the name of the defendant, the information requested, as well as the link between criminal or civil cases concerned with the information requested.

Elucidation of Article 34 of the Act ontheGeneral Provisions and Tax Procedures (UU KUP) mentioned every office, both tax officials and those who perform tasks in the field of taxation, shall not disclose confidential taxpayer regarding tax issues, among others:

1. Notice of report finance, and others reported by the taxpayer,

2. The data obtained in the framework of implementation of the inspection,

3. Document or data obtained from third parties confidential, 
4. The document and/or confidential of Taxpayer in accordance with the regulations provisions

Furthermore, the Act ontheGeneral Provisions and Tax Proceduresset the penalty of taxation officials who violate the confidentiality obligations of the post, namely:

\section{Does not fulfill the obligation secret as negligent.}

In Article 41 paragraph (1) of the Act ontheGeneral Provisions and Tax Procedures (UU KUP) mentioned "Officials who do not meet obligations due to negligence secrecy as referred to in Article 34 shall be sentenced to a maximum confinement of 1 (one) year and a maximum fine Rp.25.000.000,00 (Two thirty Five Million Rupiah) ".This is done to ensure the confidentiality of the tax will not be notified to the other party, so that the Taxpayer in delivering data and information do not hesitate, in the framework of the implementation of the Taxation Act. Disclosure of confidentiality is done because of negligence in the sense of neglect, not careful, or less heed to the obligation to keep confidential information or evidence Taxpayers who are protected by the Taxation Act violated.

\section{Deliberately not meet the obligations of secrecy.}

In Article 41 paragraph (2) of the Act Number 28 of 2007 on the Third Amendment to the Act Number 6 of 1983 on theGeneral Provisions and Tax Procedures (KUP) stated that "Officials who willfully fails to meet its obligations or someonewho causes the non-fulfillment of the obligations of officials to conceal as referred to in section 34 shall be punished with imprisonment for a period of 2 (two) years and a maximum fine of Rp50.000.000,00 (Fifty MillionRupiah).The acts done intentionally this subjected to more severe sanctionsthan the acts committed because of negligence that the concerned officials to be more careful and not do anything to divulge confidential in the interests of the individual Taxpayer.

Background theAudit Board (BPK) filed a judicial review to the Constitutional Court on the Act Number 28 of 2007 on the Third Amendment to the Act Number 6 of 1983 on theGeneral Provisions and Tax Procedures, because in the article there is an article about the procedure that limits theAudit Board (BPK) to obtain data and tax information. Article in question is Article 34 paragraph 2a (letter b) which reads exempted from the provisions referred to in paragraph (1) and (2) are: officers and/or experts appointed by the Finance Minister to give information to officials of state institutions or agencies the government is authorized to make checks in the field of public finance.

This provision is further stipulated in Decree of the Finance Minister Number 
539/KMK.04/2000 on Other Parties to Given Remarks by Officials and Experts Designated about Everything You Know or Informed to him by TaxpayersIn order Position or his Job for To Running Provisions of Taxation Legislations, the provisions containing the terms under which the other party may request Taxpayer data, among others :

(1) TheAudit Board (BPK)or the Financial and Development Supervisory Agency (BPKP);

(2) Delivering Letter of Assignment which must mention the name of the Taxpayer and information which want to known about the Taxpayer concerned; and

(3) Information that can be known is information of a general nature concerning the taxation Taxpayers and his implementation set by the Director General of Taxation.

TheAudit Board (BPK)has a mandate in accordance with Article 23Eparagraph 1 of the 1945 Constitutionof the Republic of Indonesia to carry out of Management Examination and Responsibility State Financial which is translated in the Act Number 15 of 2004 on the Management Examination and Responsibility State Financial, and the Act Number 15 of 2006 on the Audit Board.

According to the legislation above, the Audit Board is authorized to access the data and information related to the state finance management. While Article 34 of the Act Number 28 of 2007 on the Third Amendment to the Act Number 6 of 1983 on theGeneral Provisions and Tax Procedures, there is a restriction that only officials and experts assigned the Minister of Finance who shall provide such information.

The Audit Board of the Republic of Indonesia (BPK) requested the phrase"established by the Finance Minister"is have no legal power so that the Audit Boardcan request data / information to the officers and tax officials whereverof related of examination the Audit Board.In addition to restrictions on the procedure, the Audit Boardis more inhibiting assess again for the Audit Boardis as stated in the Explanation of Article 34 paragraph 2a.

The Articles specify a limited manner about the types of data / documents that may be provided to the Audit Board. The data and information contained in Elucidation of Article 34 paragraph $2 \mathrm{a}$ inadequate for the Audit Board to audit. The explanation contains restrictions on information that can be given to the Audit Boardwas contrary to Article 9 of the Act Number 15 of 2006 on the Audit Board.

Article 9 letter a assert the authority of the Audit Boardto"... define the object of inspection, planning and carrying out the inspection, determine the time and method of 
inspection as well as prepare and present inspection report". While the its letter b is "... to request information and / or documents that must be provided by each person, an organizational unit of the Central Government, Local Government, other State institutions, Bank Indonesia, State-Owned Enterprises, General Services Agency, Regional-Owned Enterprises, and institution or other entity that manages state finances" (Bolding of Researchers ).So that's it, the restriction information should be provided to the Audit Board clearly contrary to Article 9 of the Act Number 15 of 2006 on the Audit Board. In fact, Article 9 was the attribution of Section 23E the 1945 Constitutionwhich is the legal standing of the Applicant.

Results Decisions Judicial Review is the Judges of the Constitutional Court decided to rejects lawsuit "judicial review" the Audit Board of the Republic of Indonesia (BPK) because they did not have legal standingrememberingthere is no constitutional authority of the Audit Boardwhich disadvantaged.The petition of examination of the Act Number 28 of 2007 on the Third Amendment to the Act Number 6 of 1983 on theGeneral Provisions and Tax Procedures against the 1945 Constitution which submitted by the Audit Boardaccording to the Researchers, actually is an attempt to legitimize the Audit Boardexamination of all stages of tax collection as the investigation authority that can be categorized as conduct coercive optimal taxation sector monopoly that tends motivated attempts to rule out other institutions to examine the state finances ${ }^{28}$.

\section{CONCLUSIONS}

Departing from the issues that have been pointed out earlier, this paper reached the following conclusions:

1. Although the Audit Boardqualify as a party may apply for judicial review of the Act Number 28 of 2007 on the Third Amendment to the Act Number 6 of 1983 on theGeneral Provisions and Tax Procedures against the 1945 Constitution, however the case of examination the proposed actually problematic, because the Audit Board erroneousin using the argumentum a contrario that lead to differences in interpretation about the authority of state institutions, instead using the mechanism of judicial review. Besides, in fact is not a matter of dispute over the constitutional authority of state institutions, so that the Constitutional Court decides it can not be determined any loss constitutional authority

${ }^{28}$ Richard A. Epstein.(1989). Skepticism and Freedom: A Modern Case for Classical Liberalism. New York: McGraw-Hill Book, 1978, P.84. See also: Alfred J. Marrow, David Bowers and Seashore, Management by Participations (New York: Harper \& Row), P.55 
of the Audit Boardas a result of the enactment of Article 34 paragraph (2a) letter b and Elucidation of Article 34 Paragraph (2a) of the Act Number 28 of 2007 on the Third Amendment to the Act Number 6 of 1983 on theGeneral Provisions and Tax Procedures. Besides the requisite legal standing is not fulfilled so that the petition should be declared unacceptable (nietontvankelijkverklaard).

2. Legislation governing state finances, namely the Act Number 17 of 2003 on State Finance and the Act Number 15 of 2004 on the Management and State Financial Responsibility, and the Act Number 15 of 2006 on the Audit Board, has put the Audit Board (BPK) as the body tends to be monopolistic in conducting the examination of state finances, in addition to creating instability in the taxation sector.

\section{BIBLIOGRAPHY}

\section{Books, Papers, Articles}

Alberto Alesina, Nouriel Roubini and Gerald D. Cohen.(1997). Political Cycles and the Macroeconomy, Massachusetts: Massachusetts Institute of Technology

Alfred J. Marrow, David Bowers and Seashore. (1989). Management by Participations, New York: Harper and Row

Arifin P. SoeriaAtmadja. (2000). Position and Function of the Audit Boardin the Constitutional Structure of the Republic of Indonesia, Depok: Center for Constitutional Law, Faculty of Law, University of Indonesia ., (2005). Public Finance Law in Perspective, Theory, Practice and Criticism. Jakarta: Body Publisher Faculty of Law, University of Indonesia.

Bernard, Arief Sidharta,(2008). Introduction to Logic. Bandung: Refika Aditama.

The Audit Board, Getting more the Audit Board: A Popular Guide, Without the Year. Jakarta: Public Relations and Foreign Affairs Audit Board of Indonesia.

Dian Puji, N. Simatupang. (2011). Investigation Against Tax as Part of Scope of the State Finance According to the Legal Theory of Public Finance, Indonesian Legislative Journal, Vol. 8 No. 1 - April 2011, Jakarta: Directorate General of Legislation Ministry of Justice and Human Rights of the Republic of Indonesia

Sahat, Simamora, (1997). Bureaucracy. Jakarta: Rajawali Press.

Jimly, Asshiddiqie, (2005). Models Constitutional Testing Various Countries. Jakarta: Constitutional Press. ,(2006). Development and Consolidation of State Institutions Post-Reform. Jakarta: Constitutional Press.

Sudikno, Mertokusumo, (1993). Chapters about Legal Invention. Jakarta: Citra Aditya Bakti

MDA, Freeman, (2001). Introduction to Jurisprudence. London: Sweet and Maxwell Ltd.

Mark, Moore in (2001). Rethingking Democratic Accountability, in Robert D.Behn, 
Washington DC : Brookings Institution Press

Martin, P.Golding, (1984). Legal Reasoning. New York :Alfreda A. Knoff Inc.

Indonesian Regional Representatives Council,(2011).Academic Manuscript Draft of Changes the Act Number 17 of 2003 on State Finance, June, Jakarta

News Koran Sindo, Taxpayer Audit Investment Worsens, http://www.pajak2000.com/news, accessed date October 19, 2011

PW Brouwer, A. Soeteman, (1982). Logicaen Recht. Zwolle: WEJ. Tjeenk Willink.

Richard A. Epstein, (1978). Skepticism and Freedom: A Modern Case for Classical Liberalism. New York: McGraw-Hill Book.

Robert D. Lee and Ronald W. Johnson, (1975).Public Budgeting System, Baltimore : University Park Press.

WG. Van der Velden, (1988). De Ontwikkeling van de Wetgevingswetenschap, Lelystad :KoninklijkeVermande

\section{Legislations and Constitutional Court Decision}

Indonesia, the 1945 Constitution of the Republic of Indonesia

Indonesia, the Act Number 1 of 2004 on the State Treasury.

Indonesia, the Act Number 15 of 2004 on the Management Examination and Responsibility State Financial

Indonesia, the Act Number 15 of 2006 on the Audit Board.

Indonesia, the Act Number 17 of 2003 on the State Finance.

Indonesia, the Act Number 28 of 2007 on the Third Amendment to the Act Number 6 of 1983 on theGeneral Provisions and Tax Procedures.

Decision of the Constitutional Court of the Republic of Indonesia Number 3/PUUVI/2008 on Judicial Review of Law Number 28 Year 2007 on Third Amendment Act No. 6 of 1983 on General Provisions and Tax Procedures against the Constitution of the Republic of Indonesia Year 1945 